\title{
INBREEDING DEPRESSION IN MAIZE POPULATIONS OF REDUCED SIZE ${ }^{1}$
}

\author{
Félix Alonso Astete Maldonado; José Branco de Miranda Filho ${ }^{3 *}$ \\ ${ }^{2}$ Pós-Graduando em Genética e Melhoramento de Plantas - USP/ESALQ \\ ${ }^{3}$ Depto. de Genética - USP/ESALQ, C.P. 83 CEP: 13400-970 - Piracicaba, SP. \\ *Corresponding author<jbmirand@carpa.ciagri.usp.br>
}

\begin{abstract}
Inbreeding is a well known phenomenon in living beings and its immediate consequence is the decrease in the expression of quantitative traits, known as inbreeding depression. Selfing is the most common system of inbreeding in plant species; however, little has been studied with other less severe inbreeding systems, such that resulting from small population sizes. The present work consisted of the study of the inbreeding effect on quantitative traits as a consequence of reduced population size under panmixy. Three maize (Zea mays L.) populations were used in this study: $\mathrm{P}_{1}-$ ITA, population derived from the variety IACTaiúba; $P_{2}$ - represented by 30 subpopulations already submmited to reduced size $(N=5)$; and $P_{3}$ - population derived from the interpopulation cross ESALQ-PB2 $x$ ESALQ-PB3. The subpopulations and the respective parental populations were evaluated in six experiments using completely randomized blocks with four replications in Piracicaba (SP) and Anhembi (SP), Brazil, from 1997 to 1999. Estimates of inbreeding depression and components of means were obtained for the two generations in the three populations for the following traits: plant height, ear height, ear length, ear diameter, and yield traits (total ear weight and total grain weight). In all populations and for all traits and sampling generations, means of subpopulations were always smaller than mean of the base populations, however the inbreeding depression levels were smaller than expected. The highest inbreeding depression was exhibited by the yield traits, while a very small depressive effect was observed for plant height and ear height in the first generation of reduced size in populations $P_{1}$ and $P_{3}$. The component $\mathrm{A}$ (expected mean of a random sample of completely homozygous lines) was always higher than $d$ (contribution of the heterozygotes to the mean) for all traits and populations.
\end{abstract}

Key words: Zea mays, genetic drift, effective size

\section{DEPRESSÃO POR ENDOGAMIA EM POPULAÇÕES DE MILHO DE TAMANHO REDUZIDO}

\begin{abstract}
RESUMO: A endogamia é um fenômeno bastante conhecido nos seres vivos e sua consequência imediata é o decréscimo na expressão de caracteres quantitativos, conhecido por depressão por endogamia. A autofecundação é o sistema mais comum de endogamia nas espécies vegetais; entretanto, pouco tem sido estudado com outros sistemas menos severos de endogamia, como o que resulta de pequeno tamanho populacional. O presente trabalho teve por objetivo o estudo do efeito da endogamia em caracteres quantitativos, como conseqüência da redução do tamanho de população sob panmixia. Três populações de milho (Zea mays L.) foram utilizadas neste estudo: $P_{1}-$ ITA, população derivada da variedade IAC-Taiúba; $P_{2}$ - representada por 30 subpopulações previamente submetidas a tamanho reduzido $(N=5) ; P_{3}$ - população derivada do híbrido interpopulacional ESALQ-PB2 x ESALQ-PB3. As subpopulações e as respectivas populações parentais foram avaliadas em seis experimentos em blocos casualizados com quatro repetições em Piracicaba (SP) e Anhembi (SP) entre os anos de 1997 e 1999. Foram obtidas estimativas de depressão por endogamia e dos componentes de médias para as duas gerações nas três populações para os caracteres: altura da planta, altura da espiga, comprimento da espiga, diâmetro da espiga, peso de espigas e peso de grãos. Em todas as populações, para todos os caracteres e gerações de amostragem, as médias das subpopulações foram menores do que as médias das populações base, porém os níveis de depressão por endogamia foram menores do que o esperado. A partir das estimativas dos componentes A (média esperada de linhagens totalmente homozigóticas) e d (contribuição dos heterozigotos para a média), foi estimada a relação $\mathrm{A} / \mathrm{d}$, com valores maiores que 1,0 para todos os caracteres e populações.

Palavras-chave: Zea mays, deriva genética, tamanho efetivo
\end{abstract}

\section{INTRODUCTION}

One of the main objectives in maize breeding is to develop outstanding hybrids from inbred lines and selfing has been recognized as the most used method for the development of inbred lines (Hallauer, 1990).
Selfing has some advantages over other methods of inbred line development that are less severe in relation to the rate of inbreeding in each generation. One advantage is the time necessary to reach the desired level of homozygosity; however, reaching a high level of homozygosity in few generations of inbreeding may turn

\footnotetext{
${ }^{1}$ Part of the Thesis of the first author, presented to USP/ESALQ - Piracicaba, SP.
} 
to be a disadvantage in highly depressive populations, because many potentially useful lines are eliminated in the first generations as a consequence of the high homozygosity for lethal, semi-lethal and deleterious genes of large effects (Hallauer \& Miranda Filho, 1995).

Methods for inbred line development under less severe inbreeding than selfing are based on crosses between half-sibs, crosses between full-sibs, backcrossing and random mating within small size subpopulations. Crossing a small number of plants to generate subpopulations will leads to a dispersive process that causes variation of allele frequencies among subpopulations. Such a dispersive process also leads to an increase in the level of homozygosity and consequently to a decrease in the expression of quantitative traits under the control of dominant gene action (Miranda Filho, 1999). Paterniani (1995) reported on inbreeding depression in subpopulations of size $\mathrm{N}=$ 5 , obtained from two populations represented by the $F_{2}$ generations of crosses between inbred lines from the base populations ESALQ-PB2 and ESALQ-PB3. In this study, inbreeding depression varied with the base population, the studied trait and the local of evaluation; in general, inbreeding depression was higher for tassel branch number, 300 kernel weight and yield (total plot grain weight). Corrales Blandon (1996) also studied the possibility of using the random dispersive process, caused by reduced population size, as a means for the development of superior inbred lines with the accumulation of favorable factors. It was found that the increase in the proportion of homozygotes within subpopulations resulted in inbreeding depression in several traits, mainly plant height, ear height, tassel branch number and grain yield. Also, some estimates of subpopulation means and general combining ability in partial diallel cross were higher than the parental population for all the studied traits.

To study the inbreeding effect on quantitative traits, as a consequence of reduced population size under panmixy, this work was carried out using maize subpopulations of size $\mathrm{N}=4$ in two non-inbred populations and one set of inbred subpopulations already submitted to reduced size in two generations with $\mathrm{N}=5$

\section{MATERIAL AND METHODS}

Three maize (Zea mays L.) populations were submitted to sampling of reduced effective size: $P_{1}-$ ITA, population derived from the variety IAC-Taiúba; $P_{2}-$ represented by 30 subpopulations obtained by sampling in two generations of reduced size $(\mathrm{N}=5)$, starting from the $F_{2}$ generation of the cross between inbred lines derived from the populations ESALQ-PB2 e ESALQ-PB3; $P_{3}$ - population derived from the interpopulation cross ESALQ-PB2 x ESALQ-PB3. In populations $\mathrm{P}_{1}$ and $\mathrm{P}_{3}$, reduced size $(N=4)$ subpopulations were obtained through random pollination within each set of four plants:
51 and 73 in the first generation and 48 and 70 in the second generation, respectively. In $\mathrm{P}_{2}$, only 28 subpopulations were advanced for two additional generations of reduced size $(\mathrm{N}=4)$.

Subpopulations and respective parental populations were evaluated in six experiments in completely randomized blocks with four replications at Piracicaba (SP) and Anhembi (SP) from 1997 to 1999. Two experiments at Piracicaba (SP), 1997 and 1998, were used to evaluate subpopulations of $P_{1}$ and $P_{3}$ in the first cycle; two experiments at Anhembi (SP), 1998 and 1999, were used to evaluate subpopulations of $P_{1}$ and $\mathrm{P}_{3}$ in the second cycle; and two experiments in Anhembi (SP), 1999, were used to evaluate subpopulations of $P_{2}$ in the third and fourth cycles. The base populations $\left(P_{1}\right.$, $P_{2}$ and $P_{3}$ ) were included as treatments in the respective experiments. The commercial hybrid (three-way cross) MASTER (Novartis Seeds) was used as check and was intercalated systematically after ten plots within replications.

In all the experiments, the following traits were analyzed: plant height $(\mathrm{PH})$, ear height $(\mathrm{EH})$, ear length $(E L)$, ear diameter (ED), and yield traits (EY- ear yield and GY- grain yield). The inbreeding depression, on the average of subpopulations and expressed in the original unit (I), in per cent of the parental populations (I\%), and for $1 \%$ expected homozygosity $\left(I_{1 \%}\right)$, were estimated by: $\mathbf{I}=\mathrm{m}_{\mathrm{s}}-\mathrm{m}_{0}, \mathbf{I} \%=100\left(\mathrm{~m}_{\mathrm{s}}-\mathrm{m}_{0}\right) / \mathrm{m}_{0}$ and $\mathbf{I}_{1 \%}=\left(\mathrm{m}_{\mathrm{s}}-\mathrm{m}_{0}\right) /$ $100 \mathrm{~F}_{\mathrm{t}} ; \mathrm{m}_{\mathrm{s}}$ is the overall mean of sub-populations, $\mathrm{m}_{0}$ is the parental population mean, and $F_{t}$ is the inbreeding coefficient in the $t^{\text {th }}$ generation ( $t=1$ and 2 for populations $\mathrm{P}_{1}$ and $\mathrm{P}_{3}$ and $\mathrm{t}=3$ and 4 for population $\mathrm{P}_{2}$ ); $\mathrm{F}$ is the general notation for Wright's coefficient of inbreeding. The inbreeding coefficients are: $F_{1}=0.125$ and $F_{2}=0.234$; and $F_{3}=0.291$ and $F_{4}=0.379$. The hybrid check mean $\left(m_{c}\right)$ was included in the results for general comparisons, except for the results referring to inbreeding depression because the check was not submitted to inbreeding.

For comparison with other reports in the literature, which used one generation of selfing $(50 \%$ expected homozygosity) to study inbreeding depression, our results were adjusted to $F=0.5$. The expected contribution of the homozygotes $(A=\mu+a)$ and heterozygotes $(d)$ to the population mean were estimated by $A=\left(\frac{1}{F}\right) m_{s}-\left(\frac{1-F_{t}}{F}\right) m_{0}$ and $d=\frac{1}{F_{1}}\left(m_{0}-m_{s}\right)=-100 I_{1 \%}$ (Lima et al., 1984; Paterniani, 1995; Miranda Filho, 1999).

\section{RESULTS AND DISCUSSION}

The analysis of variance for the six traits showed significance for the variation among subpopulations in the six experiments at probability $P<0.01$, except $G Y$ in population $\mathrm{P} 3$ at $\mathrm{Piracicaba}$ with significance at $\mathrm{P}<0.05$ (Table 1). The expressive difference among subpopulations of reduced size was expected as based on the theory that the subdivision of a population into subpopulations of smaller size leads to a dispersive 
Table 1 - Analysis of variance for six traits in six experiments.

\begin{tabular}{|c|c|c|c|c|c|c|c|}
\hline Source ${ }^{1}$ & d.f. & $\mathrm{PH}$ & $\mathrm{EH}$ & $\mathrm{EL}$ & ED & EY & GY \\
\hline & \multicolumn{7}{|c|}{ Population $\mathrm{P}^{1}: 1^{\text {st }}$ generation (Piracicaba, $\left.\mathrm{SP}\right)^{2}$} \\
\hline Subpopulation & 50 & $3.598^{* *}$ & $2.878^{\star \star}$ & $2.299^{* *}$ & $0.175^{* *}$ & $1.440^{* *}$ & $0.959^{* *}$ \\
\hline Error & 150 & 0.755 & 0.562 & 0.918 & 0.044 & 0.224 & 0.151 \\
\hline \multirow[t]{2}{*}{ Coef. variation \% } & & 4.0 & 6.1 & 7.4 & 6.0 & 15.6 & 17.7 \\
\hline & \multicolumn{7}{|c|}{ Population $\mathrm{P}^{1}: 2^{\text {nd }}$ generation $(\text { Anhembi, SP })^{3}$} \\
\hline Subpopulation & 47 & $15.100^{\star \star}$ & $12.669^{* *}$ & $2.222^{\star *}$ & $0.176^{\star *}$ & $1.219^{\star \star}$ & $0.894^{\star *}$ \\
\hline Error & 141 & 2.901 & 2.044 & 0.607 & 0.027 & 0.163 & 0.095 \\
\hline \multirow[t]{2}{*}{ Coef. variation \% } & & 6.9 & 11.8 & 6.1 & 4.5 & 13.1 & 13.8 \\
\hline & \multicolumn{7}{|c|}{ Population $\mathrm{P}^{2}: 3^{\text {rd }}$ generation (Anhembi, SP) ${ }^{4}$} \\
\hline Subpopulation & 27 & $10.491^{* *}$ & $6.623^{* *}$ & $4.209^{* \star}$ & $0.165^{\star *}$ & $1.519^{* \star}$ & $1.048^{* \star}$ \\
\hline Error & 81 & 5.843 & 3.051 & 0.985 & 0.046 & 0.316 & 0.228 \\
\hline \multirow[t]{2}{*}{ Coef. variation \% } & & 9.5 & 13.4 & 7.9 & 5.3 & 14.8 & 15.7 \\
\hline & \multicolumn{7}{|c|}{ Population $\mathrm{P}^{2}: 4^{\text {th }}$ generation $(\text { Anhembi, SP })^{4}$} \\
\hline Subpopulation & 27 & $10.260^{\star *}$ & $11.083^{* *}$ & $4.509^{\star *}$ & $0.150^{* *}$ & $0.948^{* *}$ & $0.635^{\star \star}$ \\
\hline Error & 81 & 3.478 & 2.026 & 1.045 & 0.047 & 0.244 & 0.152 \\
\hline \multirow[t]{2}{*}{ Coef. variation $\%$} & & 8.9 & 12.3 & 8.6 & 5.6 & 13.9 & 14.1 \\
\hline & \multicolumn{7}{|c|}{ Population $\mathrm{P}^{3}: 1^{\text {st }}$ generation (Piracicaba, $\left.\mathrm{SP}\right)^{2}$} \\
\hline Subpopulation & 72 & $3.761^{* *}$ & $2.978^{* *}$ & $3.296^{* *}$ & $0.124^{* *}$ & $1.061^{* *}$ & $0.736^{*}$ \\
\hline Error & 216 & 1.745 & 1.099 & 1.386 & 0.058 & 0.756 & 0.487 \\
\hline \multirow[t]{2}{*}{ Coef. variation $\%$} & & 6.3 & 9.0 & 7.5 & 6.1 & 17.7 & 18.0 \\
\hline & \multicolumn{7}{|c|}{ Population P3: $2^{\text {nd }}$ generation $(\text { Anhembi, SP })^{3}$} \\
\hline Subpopulation & 69 & $13.372^{\star *}$ & $10.422^{\star \star}$ & $4.006^{\star *}$ & $0.153^{* *}$ & $2.294^{\star *}$ & $1.737^{* *}$ \\
\hline Error & 207 & 6.522 & 5.075 & 1.316 & 0.042 & 0.410 & 0.294 \\
\hline Coef. variation \% & & 6.5 & 9.6 & 8.0 & 5.1 & 13.1 & 13.7 \\
\hline
\end{tabular}

${ }^{1}$ Mean squares for replications (not shown) were significant in most instances.

21997/98 , ${ }^{3} 1998 / 99,{ }^{4}$ off-season ("safrinha") 1999.

process as a consequence of genetic drift (Crow \& Kimura, 1970). The variance ratio (subpopulations : error; values not shown) showed the higher estimates for $G Y$ and EY, except for population P3 at Piracicaba, suggesting a higher dispersion among subpopulations for these traits. It is therefore reasonable to suppose that more complex traits, controlled by a large number of loci, should exhibit a wider dispersion of subpopulation means.

The coefficients of variation (CV) were in general higher than the observed in other reports, particularly for yield traits (GY and EY). However, the results do not indicate necessarily a low precision of the experiments, because $C V$ is influenced by the mean and in all experiments the general mean represents subpopulations with some level of inbreeding, whose means are below the non inbred populations as a consequence of inbreeding depression. In fact CV in the range of $13 \%$ to $18 \%$ can be considered as acceptable for inbred subpopulations. Blandon (1996) worked with inbred subpopulations and reported CV's of $15.6 \%$ and $19.5 \%$ for yield in two locations; mean yields were 4.43 and 3.06 $\mathrm{t} \mathrm{ha}^{-1}$, respectively.

Observed means in the base populations $\left(\mathrm{P}_{1}, \mathrm{P}_{2}\right.$ and $\mathrm{P}_{3}$ ) and derived sub-populations are shown for six traits (Table 2). Some direct comparisons between populations and generations are not possible because differences between locations and planting dates. The performance of populations $\mathrm{P}_{1}$ and $\mathrm{P}_{3}$ can be compared in both first and second generations because experiments were conducted in Piracicaba (SP) and Anhembi (SP) in 1997/98 and 1998/99, respectively. Very small differences were observed between populations $\mathrm{P}_{1}$ and $\mathrm{P}_{3}$ for $\mathrm{PH}$ and $\mathrm{EH}$ in both generations; the same conclusion holds for the comparison between populations and hybrid check. For $E L$ and ED, population $P_{1}$ showed smaller values than $\mathrm{P}_{3}$ and check in both generations. Population $\mathrm{P}_{3}$ showed slightly higher EL and slightly smaller ED than hybrid check in both generations. For yield traits (EY and GY) both populations $\left(\mathrm{P}_{1}\right.$ and $\left.\mathrm{P}_{3}\right)$ showed smaller values than the hybrid check in both generations. However, the lower yielding performance was for $\mathrm{P}_{1}$ with grain yield representing $43.2 \%$ and $44.1 \%$ of the check yield in the first and second generations, respectively. On the other hand, grain yield for $\mathrm{P}_{3}$ represented $77.3 \%$ and $79.9 \%$ of the check yield, respectively. The superiority of $P_{3}$ over $\mathrm{P}_{1}$ for yield traits is thus evident; grain yield for $\mathrm{P}_{3}$ represented $178.2 \%$ and $178.9 \%$ relative to $P_{1}$ in the 
Table 2 - Observed means for six traits in three base populations $\left(m_{0}\right)$ and respective subpopulations $\left(m_{s}\right)$ derived from reduced effective size and in a hybrid check $\left(\mathrm{m}_{\mathrm{c}}\right)$.

\begin{tabular}{|c|c|c|c|c|c|c|}
\hline \multirow[t]{3}{*}{ Traits } & \multicolumn{6}{|c|}{ Base population $\mathrm{P}_{1}$} \\
\hline & \multicolumn{3}{|c|}{$1^{\text {st }}$ generation (Piracicaba, SP) ${ }^{1}$} & \multicolumn{3}{|c|}{$2^{\text {nd }}$ generation (Anhembi, SP) $)^{2}$} \\
\hline & $\mathrm{m}_{0}$ & $m_{s}$ & $\mathrm{~m}_{\mathrm{c}}$ & $\mathrm{m}_{0}$ & $\mathrm{~m}_{\mathrm{s}}$ & $\mathrm{m}_{\mathrm{c}}$ \\
\hline Plant height (m) & 2.193 & 2.172 & 2.116 & 2.152 & 2.053 & 2.118 \\
\hline Ear height (m) & 1.237 & 1.232 & 1.186 & 1.238 & 1.133 & 1.197 \\
\hline Ear leng th $(\mathrm{cm})$ & 13.17 & 12.91 & 14.59 & 13.24 & 12.67 & 14.69 \\
\hline Ear diameter $(\mathrm{cm})$ & 3.55 & 3.52 & 4.43 & 3.75 & 3.66 & 4.46 \\
\hline Ear yield $\left(\mathrm{t} \mathrm{ha}^{-1}\right)$ & 3.164 & 3.035 & 6.181 & 3.266 & 3.069 & 6.543 \\
\hline \multirow[t]{4}{*}{ Grain yield $\left(\mathrm{t} \mathrm{ha}^{-1}\right)$} & 2.293 & 2.172 & 5.314 & 2.516 & 2.224 & 5.700 \\
\hline & \multicolumn{6}{|c|}{ Base population $\mathrm{P}_{2}$} \\
\hline & \multicolumn{3}{|c|}{$3^{\text {rd }}$ generation $(\text { Anhembi, SP })^{3}$} & \multicolumn{3}{|c|}{$4^{\text {th }}$ generation $\left(\right.$ Anhembi, SP) ${ }^{3}$} \\
\hline & $\mathrm{m}_{0}$ & $m_{s}$ & $\mathrm{~m}_{\mathrm{c}}$ & $\mathrm{m}_{0}$ & $\mathrm{~m}_{\mathrm{s}}$ & $m_{c}$ \\
\hline Plant height (m) & 1.804 & 1.584 & 1.953 & 1.868 & 1.580 & 1.943 \\
\hline Ear height (m) & 0.953 & 0.822 & 1.133 & 1.010 & 0.828 & 1.147 \\
\hline Ear leng th $(\mathrm{cm})$ & 13.67 & 12.54 & 14.58 & 13.43 & 11.91 & 14.76 \\
\hline Ear diameter $(\mathrm{cm})$ & 4.18 & 4.07 & 4.20 & 4.12 & 3.91 & 4.22 \\
\hline Ear yield $\left(\mathrm{t} \mathrm{ha}^{-1}\right)$ & 4.171 & 3.793 & 4.62 & 4.133 & 3.553 & 4.312 \\
\hline \multirow[t]{4}{*}{ Grain yield $\left(\mathrm{t} \mathrm{ha} \mathrm{H}^{-1}\right)$} & 3.401 & 3.042 & 3.59 & 3.201 & 2.774 & 3.366 \\
\hline & \multicolumn{6}{|c|}{ Base population $\mathrm{P}_{3}$} \\
\hline & \multicolumn{3}{|c|}{$1^{\text {st }}$ generation (Piracicaba, SP $)^{1}$} & \multicolumn{3}{|c|}{$2^{\text {nd }}$ generation (Anhembi, SP) $)^{2}$} \\
\hline & $\mathrm{m}_{0}$ & $\mathrm{~m}_{\mathrm{s}}$ & $\mathrm{m}_{\mathrm{c}}$ & $\mathrm{m}_{0}$ & $\mathrm{~m}_{\mathrm{s}}$ & $\mathrm{m}_{\mathrm{c}}$ \\
\hline Plant height (m) & 2.105 & 2.091 & 2.109 & 2.180 & 2.089 & 2.137 \\
\hline Ear height $(m)$ & 1.167 & 1.160 & 1.191 & 1.249 & 1.176 & 1.208 \\
\hline Ear length $(\mathrm{cm})$ & 15.92 & 15.59 & 14.67 & 14.86 & 14.35 & 14.66 \\
\hline Ear diameter $(\mathrm{cm})$ & 4.02 & 3.96 & 4.48 & 4.10 & 3.97 & 4.46 \\
\hline Ear yield $\left(\mathrm{t} \mathrm{ha}^{-1}\right)$ & 5.143 & 4.894 & 5.968 & 5.391 & 4.898 & 6.473 \\
\hline Grain yield $\left(\mathrm{t} \mathrm{ha}^{-1}\right)$ & 4.086 & 3.880 & 5.287 & 4.500 & 3.971 & 5.633 \\
\hline
\end{tabular}

11997/98, ${ }^{2} 1998 / 99,{ }^{3}$ off-season ("safrinha") 1999.

first and second generation, respectively. The differences between yields of $P_{1}$ and $P_{3}$ can be partly attributed to environmental effects by favoring the expression of susceptibility to pests and diseases. However, $\mathrm{P}_{3}$ has shown good performance in several other experiments (Basso, 1999; Miranda Filho et al., 2001).

The base population $P_{2}$ and its sub-populations in the third and fourth generations of reduced size were evaluated only at Anhembi in off-season planting ("safrinha") in 1999. Therefore, the results of these experiments are not directly comparable with those referring to $P_{1}$ and $P_{3}$, but they are comparable between themselves. For the base population, means of $\mathrm{PH}$ and $\mathrm{EH}$ were slightly smaller than hybrid check in both generations. EL and ED also showed smaller means than the hybrid check; these two components of grain yield possibly contributed to the lower yield of the base populations in both generations. In fact, grain yield of population $\mathrm{P}_{2}$ represented $97.2 \%$ and $95.1 \%$ of the hybrid check in the third and fourth generations, respectively.
Means of sub-populations $\left(m_{s}\right)$ derived from the three populations $\left(P_{1}, P_{2}\right.$ and $\left.P_{3}\right)$ were always smaller than the base populations $\left(\mathrm{m}_{0}\right)$ for all the six studied traits in all generations and $\mathrm{m}_{\mathrm{s}}$ varied from $82.0 \%$ to $99.6 \%$ in relation to $m_{0}$ These effects are due to the depression caused by inbreeding as a consequence of the reduced size of the sub-populations. Some parameters related to inbreeding depression and components of means were estimated (Table 3). Inbreeding depression (I) was firstly estimated in the original units for all traits. The most negative estimates were for for population $P_{2}$, as expected because it was in a higher level of inbreeding; i.e., $F=0.291$ and $F=0.379$ in the third and fourth generations, respectively; $F$ being Wright's coefficient of inbreeding. When expressed in percent of the original meand it was seen that the highestl was for $\mathrm{PH}$ and $\mathrm{EH}$, followed by yield traits. In the populations $\mathrm{P}_{1}$ and $\mathrm{P}_{3}$, at a lower level of inbreeding ( $F=0.125$ in the first cycle and $\mathrm{F}=0.234$ in the second cycle), the highest I was for grain yield in the first cycle $\left(-5.3 \%\right.$ in $\mathrm{P}_{1}$ and $-5.0 \%$ in $\mathrm{P}_{5}$ ); for $\mathrm{PH}$ and $\mathrm{EH}$, I was very low $(<1 \%)$ in the first cycle) 
Table 3 - Estimates of the inbreeding depression expressed in original units (I), in percent of the base population mean (I\%) and for $1 \%$ expected homozygosity $\left(\mathbf{I}_{1 \%}\right)$ and expected contribution of homozygotes $(A)$ and heterozygotes (d) to the mean for three populations in two different generations of reduced effective size.

\begin{tabular}{|c|c|c|c|c|c|c|c|c|c|c|}
\hline & \multicolumn{10}{|c|}{ Base population $\mathrm{P}_{1}$} \\
\hline & \multicolumn{5}{|c|}{$1^{\text {st }}$ generation (Piracicaba, SP $)^{1}$} & \multicolumn{5}{|c|}{$2^{\text {nd }}$ generation $(\text { Anhembi, SP })^{2}$} \\
\hline & $\mathbf{I}$ & $\% y$ & $11 \%$ & A & $d$ & $\mathbf{I}$ & $1 \%$ & $\mid 1 \%$ & A & $d$ \\
\hline Plant height (m) & 0.021 & -1.0 & -1.7 & 2.025 & 0.168 & -0.099 & -4.6 & -4.2 & 1.730 & 0.422 \\
\hline Ear height (m) & -0.005 & -0.4 & -0.4 & 1.197 & 0.040 & -0.105 & -8.5 & -4.5 & 0.790 & 0.448 \\
\hline Ear length $(\mathrm{cm})$ & -0.26 & -2.0 & -20.8 & 11.090 & 2.080 & -0.57 & -4.3 & -24.3 & 10.809 & 2.431 \\
\hline Ear diameter $(\mathrm{cm})$ & -0.03 & -0.8 & -2.4 & 3.310 & 0.240 & -0.09 & -2.4 & -3.8 & 3.366 & 0.384 \\
\hline Ear yield $\left(\mathrm{t} \mathrm{ha}^{-1}\right)$ & -0.129 & -4.1 & -10.3 & 2.132 & 1.032 & -0.197 & -6.0 & -8.4 & 2.426 & 0.840 \\
\hline \multirow[t]{4}{*}{ Grain yield $\left(\mathrm{t} \mathrm{ha}^{-1}\right)$} & -0.121 & -5.3 & -9.7 & 1.325 & 0.968 & -0.292 & -11.6 & -12.5 & 1.271 & 1.245 \\
\hline & \multicolumn{10}{|c|}{ Base population $\mathrm{P}_{2}$} \\
\hline & \multicolumn{5}{|c|}{$3^{\text {rd }}$ generation $(\text { Anhe mbi, SP })^{3}$} & \multicolumn{5}{|c|}{$4^{\text {th }}$ generation $(\text { Anhe } \mathrm{mbi}, \mathrm{SP})^{3}$} \\
\hline & $\mathbf{I}$ & \%y & $11 \%$ & A & $\mathrm{d}$ & $\mathbf{I}$ & $1 \%$ & $11 \%$ & A & $\mathrm{d}$ \\
\hline Plant height (m) & -0.22 & -12.2 & -7.6 & 1.049 & 0.755 & -0.288 & -15.4 & -7.6 & 1.110 & 0.758 \\
\hline Ear height (m) & -0.131 & -13.7 & -4.5 & 0.503 & 0.450 & -0.182 & -18.0 & -4.8 & 0.531 & 0.479 \\
\hline Ear length $(\mathrm{cm})$ & -1.13 & -8.3 & -38.8 & 9.790 & 3.880 & -1.52 & -11.3 & -40.0 & 9.428 & 4.002 \\
\hline Ear diameter $(\mathrm{cm})$ & -0.11 & -2.6 & -3.8 & 3.802 & 0.378 & -0.21 & -5.1 & -5.5 & 3.567 & 0.553 \\
\hline Ear yield $\left(\mathrm{t} \mathrm{ha}^{-1}\right)$ & -0.378 & -9.1 & -13.0 & 2.873 & 1.298 & -0.58 & -14.0 & -15.3 & 2.606 & 1.527 \\
\hline \multirow[t]{4}{*}{ Grain yield (t ha-1) } & -0.359 & -10.6 & -12.3 & 2.168 & 1.233 & -0.427 & -13.3 & -11.2 & 2.077 & 1.124 \\
\hline & \multicolumn{10}{|c|}{ Base population $\mathrm{P}_{3}$} \\
\hline & \multicolumn{5}{|c|}{$1^{\text {st }}$ generation (Piracicaba, SP $)^{1}$} & \multicolumn{5}{|c|}{$2^{\text {nd }}$ generation (Anhembi, SP) ${ }^{2}$} \\
\hline & $\mathbf{I}$ & 1\%y & $11 \%$ & A & $\mathrm{d}$ & $\mathbf{I}$ & $1 \%$ & $11 \%$ & A & $\mathrm{d}$ \\
\hline Plant height (m) & -0.014 & -0.7 & -1.1 & 1.993 & 0.112 & -0.091 & -4.2 & -3.9 & 1.792 & 0.388 \\
\hline Ear height (m) & -0.007 & -0.6 & -0.6 & 1.111 & 0.056 & -0.073 & -5.8 & -3.1 & 0.938 & 0.311 \\
\hline Ear length $(\mathrm{cm})$ & -0.33 & -2.1 & -26.4 & 13.280 & 2.640 & -0.51 & -3.4 & -21.8 & 12.685 & 2.175 \\
\hline Ear diameter $(\mathrm{cm})$ & -0.06 & -1.5 & -4.8 & 3.540 & 0.480 & -0.13 & -3.2 & -5.5 & 3.546 & 0.554 \\
\hline Ear yield $\left(\mathrm{t} \mathrm{ha}^{-1}\right)$ & -0.249 & -4.8 & -19.9 & 3.151 & 1.992 & -0.493 & -9.1 & -21.0 & 3.288 & 2.103 \\
\hline Grain yield (t ha $\left.{ }^{-1}\right)$ & -0.206 & -5.0 & -16.5 & 2.438 & 1.648 & -0.529 & -11.8 & -22.6 & 2.244 & 2.256 \\
\hline
\end{tabular}

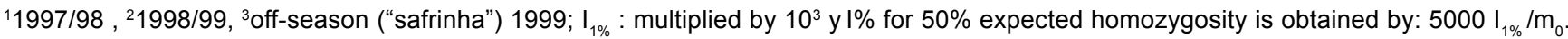

and more expressive (>4\%) in the second cycle. Also, in the second cycle, I was around $11 \%$ for grain yield in both populations. For all populations, I at the actual inbreeding level was adjusted to $50 \%$ expected homozygosity and the results were below the expected. In fact, estimated I for grain yield adjusted to $F=0.5$, which is the expected homozygosity for $S_{1}$ (selfed) progenies, varied from $18.1 \%$ to $24.8 \%$ (results not shown), considering all populations and generations. Lima et al. (1984) reported inbreeding depression in $S_{1}$ progenies of 32 Brazilian maize populations, varying from 27.0 to $59.9 \%$ for grain yield, 6.6 to $20.3 \%$ for $\mathrm{PH}$ and 6.9 to $27.4 \%$ for $\mathrm{EH}$. It was also reported that populations derived from inbred lines exhibited lower inbreeding depression (34\% less) than open-pollinated varieties which were never submitted to inbreeding. In conclusion, selection under inbreeding leads to a decrease in the genetic load, mainly that caused by recessive genes of large effects.

Other results of inbreeding depression for yield in $S_{1}$ progenies have shown average decreases varying from $37.5 \%$ to $64.0 \%$ (Vianna et al., 1982; Gama et al. 1985; Naspolini Filho \& Vencovsky, 1982; Moro, 1982; Mota, 1984; Miranda Filho \& Meirelles, 1986; Marques, 1988; Terasawa Jr., 1983; Nass \& Miranda Filho, 1995; Packer, 1998). Farias Neto \& Miranda Filho (2000) also reported on inbreeding depression for $\mathrm{PH}, \mathrm{EH}$ and tassel traits in subpopulations divergently selected for tassel size. The low inbreeding depression expected for $50 \%$ homozygosity can be due to the low exposure of the potential genetic load as a consequence of low levels of homozygosity resulting from low inbreeding in populations of reduced size. On the other hand, in $S_{1}$ progenies obtained by selfing the exposure of genetic load due to recessive genes of large effects (detrimental and deleterious genes) is much higher than in sub-populations of reduced size.

For EL and ED, small effects of inbreeding depression were observed in general. Population $\mathrm{P}_{2}$, at a higher level of homozygosity, inbreeding depression was higher for EL $(-8.3 \%$ and $-11.3 \%)$ than for ED 
$(-2.6 \%$ and $-5.1 \%)$ in the third and fourth generations, respectively. For populations $\mathrm{P}_{1}$ and $\mathrm{P}_{3}$, at lower levels of homozygosity, inbreeding depression was $<5 \%$ for both traits, considering both populations and generations. Lower inbreeding depression is indicative of lower levels of dominance of genes controlling the trait (Miranda Filho, 1999).

Estimates of the expected mean of completely homozygous lines $(A=m+a)$ were always higher than the contribution of heterozygotes (d) to the mean (Table 3 ). The ratio $A / d$ (not shown) was always smaller for yield traits, indicating higher levels of dominance of genes controlling the trait. Similar results were reported by Nass \& Miranda Filho, 1995). Lima et al. (1984) reported on estimates of $A / d<1$ in some populations, which were indicative of high levels of inbreeding depression.

The low levels of inbreeding depression at moderate levels of homozygosity indicates that more vigorous inbred lines can be developed under a continuous elimination of the potential genetic load, as emphasized by Hallauer (1980) and Hallauer \& Miranda Filho ( 1995).

\section{REFERENCES}

BASSO, C.M. Síntese de compostos de milho (Zea mays L.) com resistência ao "complexo de enfezamento". Piracicaba, 1999. 122p. Tese (Doutorado) - Escola Superior de Agricultura "Luiz de Queiroz", Universidade de São Paulo.

CORRALES BLANDÓN, S. Efeito da deriva genética sobre caracteres quantitativos em uma população de milho (Zea mays L.) Piracicaba, 1996. 90p. Tese (Doutorado) - Escola Superior de Agricultura "Luiz de Queiroz", Universidade de São Paulo.

FARIAS NETO, A.L.; MIRANDA FILHO, J.B. Inbreeding in two maize subpopulations selected for tassel size. Scientia Agricola, v.57, p.487490, 2000

GAMA, E.E.G.; VIANNA, R.T.; NASPOLI FILHO, V.; MAGNAVACA, R. Efeito depressivo da endogamia em gerações avançadas de quatro tipos genéticos de híbridos de milho. Pesquisa Agropecuária Brasileira, v.20, p.1293-1300, 1985.

HALLAUER, A.R. Relation of quantitative genetics to applied maize breeding Brazilian Journal of Genetics, v.3, p.207-233, 1980.

HALLAUER, A.R. Methods used in developing maize inbreds. Maydica, v. 35 , p.1-16, 1990

HALLAUER, A.R.; MIRANDA FILHO, J.B. Quantitative genetics in maize breeding. 2.ed. Ames: lowa State University Press, 1995.
LIMA, M.; MIRANDA FILHO, J.B.; GALLO, P.B. Inbreeding depression in Braziliam populations of maize (Zea mays L.) Maydica, v.29, p.203-215. 1984.

MARQUES, J.R.B. Seleção recorrente com endogamia em duas populações de milho (Zea mays L.) Piracicaba, 1988. 143p. Dissertação (Mestrado) Escola Superior de Agricultura "Luiz de Queiroz", Universidade de São Paulo.

MIRANDA FILHO, J.B. de. Inbreeding and heterosis. In: COORS, J.G.; PANDEY, S. (Ed.) The genetics and exploitation of heterosis in crops. Madison: ASA, 1999. p.69-80.

MIRANDA FILHO, J.B. de; GIAVENO, C.D. Variabilidade genética na população de milho GNA 01. In: XXIII CONGRESSO NACIONAL DE MILHO E SORGO, 23., Uberlândia, 2000. Anais. Uberlândia, 2000.

MIRANDA FILHO, J.B. de; MEIRELLES, W.F. Depressão por endogamia em progênies $S_{1}$ de duas populações de milho. In: CONGRESSO NACIONAL DE MILHO E SORGO, 16., Belo Horizonte, 1986. Anais. Sete Lagoas: EMBRAPA, CNPMS, 1986. p.320-327.

MIRANDA FILHO, J.B. REIS, A.J.S., SILVA R.M.; COSTA, F.M.P. Avaliação de progênies $S_{1}$ provenientes de várias populações de milho em "top crosses". Genetics and Molecular Biology, v.23, p.544. 2000. Supplement.

MIRANDA FILHO, J.B.; REGITANO NETO, A.; NASS, L.L.. 2001. Avaliação de populações de milho para resistência a doenças foliares. Fitopatologia Brasileira, v.26, p.390, 2001. Suplemento

MÔRO, J.R. Efeito da alta intensidade de seleção no melhoramento de milho (Zea mays L.). Piracicaba, 1982. 52p. Dissertação (Mestrado) - Escola Superior de Agricultura "Luiz de Queiroz", Universidade de São Paulo.

MOTA, M.G.C. Comportamento de progênies de meios irmãos e S1 na variedade de milho (Zea mays L.) Centralmex. Piracicaba, 1974. 73p. Dissertação (Mestrado) - Escola Superior de Agricultura "Luiz de Queiroz", Universidade de São Paulo.

NASPOLI FILHO, V.; VENCOVSKY, R. Avaliaçào de duas mil progênies $S$ da cultivar de milho BR 105. In: CONGRESSO NACIONAL DE MILHO E SORGO, 14., Florianópolis, 1982. Resumos. Florianópolis: EMPASC, 1982. p.25.

NASS, L.L.; MIRANDA FILHO, J.B. de. Inbreeding depression rates of semiexotic maize (Zea mays L.) populations. Revista Brasileira de Genética, v.18, p.585-592, 1995.

PACKER, D. Variabilidade genética e endogamia em quatro populações de milho (Zea mays L.) Piracicaba, 1998. 102p. Tese (Doutorado) - Escola Superior de Agricultura "Luiz de Queiroz", Universidade de São Paulo.

PATERNIANI, M.E.A.G.Z. Efeitos da redução do tamanho de populações de milho (Zea mays L.) Piracicaba, 1995. 117p. Tese (Doutorado) - Escola Superior de Agricultura "Luiz de Queiroz", Universidade de São Paulo.

TERESAWA JR., F. Seleção recorrente com endogamia em duas populações de milho: avaliação quantitativa e perspectiva para seleção de híbridos. Piracicaba, 1993. 169p. Dissertação (Mestrado) - Escola Superior de Agricultura "Luiz de Queiroz", Universidade de São Paulo.

VIANNA, R.T.; GOMES e GAMA, E.E.; NASPOLI FILHO, V.; MÔRO, J.R.; VENCOVSKY, R. Inbreeding depression of several introduced populations of maize (Zea mays L.) Maydica, v.27, p.151-157, 1982.

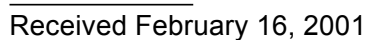

